\title{
Fermentation profile and nutritive value of maize silage with Brachiaria species
}

\author{
Daniel Augusto Alves Teixeira ${ }^{1}$, Kátia Aparecida de Pinho Costa ${ }^{2}$, Wender Ferreira de Souza ${ }^{2}$, Eduardo da \\ Costa Severiano ${ }^{2}$, Kátia Cylene Guimarães ${ }^{2}$, Jessika Torres da Silva², Suelen Soares Oliveira², Mariana \\ Borges de Castro Dias ${ }^{2}$
}

\author{
${ }^{1}$ Graduate Program in Animal Science, Goias Federal University, Goiânia-GO, Brazil \\ ${ }^{2}$ Graduate Program in Agricultural Sciences/Agronomy and Animal Science, Goiano Federal Institute, Rio Verde-GO, \\ Brazil
}

*Corresponding author: katia.costa@ifgoiano.edu.br

\begin{abstract}
The production of mixed silages is a technique that has emerged as a viable alternative for supplying nutrients during food-shortage periods in the dry season, in addition to guaranteeing the highest ensiled mass production. The aim of this study was to evaluate the fermentation profile and nutritional value of maize silage with Brachiaria species. The experiment was carried out under a completely randomized experimental design with four replications. The treatments comprised the following types of silage: maize; Congo grass; Xaraes palisadegrass; Paiaguas palisadegrass; maize $+30 \%$ Congo grass; maize $+30 \%$ Xaraes palisadegrass; and maize $+30 \%$ Paiaguas palisadegrass. For ensilage, maize and grasses were harvested in a 105-day cycle at a depth of $20 \mathrm{~cm}$ from the soil surface. According to the results, the maize silage and mixed silages presented an adequate fermentation profile and improved nutritional value. Among the investigated Brachiaria species, Paiaguas palisadegrass emerged because of its protein increase and low ADF content; therefore, this species is recommended for use in mixed silage production. Thus, mixed silage can be used as an alternative for animal feed supplementation.
\end{abstract}

Keywords: composition bromatological, fermentation, mixed silage, tropical forage, Zea mays L.

\section{Introduction}

The intensification of the production processes of beef and dairy farming in Brazil has promoted an increase in the amount and quality of feed resources for animals, especially in periods of forage shortage. In this context, high-quality silage production has become a viable alternative to forage system maintenance, as it overcomes the food shortage period and contributes to improving the animal production indices of Brazilian herds (Machado et al., 2011). Among the forages indicated for silage production, maize is the main bulk source used in rural areas (Cozzi et al., 2008). Maize is considered a standard crop species with great importance; its use has expanded in recent years, as maize has become the main off-season crop species in central Brazil (Garcia et al., 2013). This growth in maize production is due to the innumerable applications of this cereal within a farm. With regard to silage production, maize presents great production potential, an appropriate dry matter (DM) content, a high soluble carbohydrate content and a low buffer capacity (Anésio et al., 2017). The use of maize hybrids with high production potential allows the producer to select the best hybrid for their region (Paziani et al., 2009). On the other hand, the silage production of Brachiaria genus grasses has been increasing in recent years because these forages present great production potential associated with good forage quality, leading to positive results (Costa et al., 2011; Perim et al., 2014; Epifanio et al., 2014). The interest in silage production from species of this genus represents an economic strategy for producers since this type of forage is already established on many properties, thus decreasing its cost (Mendes et al., 2014). Grass silages present some interesting advantages, such as a high annual yield per area, perennial nature, low loss risk and high harvest flexibility. However, they also present some unfavourable aspects, such as a low content of soluble carbohydrates, which are required for adequate fermentation, a low dry matter content at cutting time, a high buffer capacity (Borges et al., 2018) and a lower energy value compared with maize (Perim et al., 2014). Thus, alternative silage production from annual crops with tropical forages has arisen, either in an intercropped form (Costa et al., 2018; Souza et al., 2019; Oliveira et al., 2020; Santos et al., 2020) or with forage added in the annual culture (Cruvinel et al., 2017; Paludo et al., 2020). In this context, maize silage with tropical forages can provide benefits such as balancing the nutritive value, with an increase in the crude protein content, thereby increasing silage mass production in addition to the flexibility of use, constituting an important alternative in the off season. The aim of this study was to evaluate the fermentation profile and nutritive value of maize silage with Brachiaria species. The examined hypothesis was that the addition of Brachiaria species contributes to improving the quality of exclusive maize silage by altering the crude protein concentration. Mixed 
silages present a better fermentative profile compared with that of the exclusive silages of Brachiaria species.

\section{Results}

The fermentation characteristics: $\mathrm{pH}$, buffer capacity, $\mathrm{N}-\mathrm{NH}_{3}$, and organic acids, and chemical-bromatological characteristics: dry matter (DM), crude protein (CP), ether extract (EE), total digestible nutrients (TDN), neutral detergent fibre (NDF), acid detergent fibre (ADF), lignin and in vitro dry matter digestibility (IVDMD) were influenced $(p<0.05)$ by the different treatments.

The evaluation of the $\mathrm{pH}$ (Table 2) showed the lowest value for exclusive maize silage, followed by maize silage with the addition of $30 \%$ Brachiaria species. The highest values were found for the exclusive grass silages, which showed increases of 28.37 and $13.09 \%$, respectively, in relation to the maize silage and that with the addition of Brachiaria species.

A similar behaviour to that of the $\mathrm{pH}$ occurred with the buffer capacity (Table 2), where the exclusive maize silage presented the lowest value, while the exclusive grass silages exhibited higher values. The inclusion of Brachiaria species in the maize silage at $30 \%$ resulted in a reduction in the buffer capacity. Higher $\mathrm{N}-\mathrm{NH}_{3}$ contents were observed for exclusive Brachiaria species silages (Table 2), while maize silage exhibited lower protein deterioration, resulting in lower $\mathrm{N}-\mathrm{NH}_{3}$ contents compared with those of the other silages. The inclusion of $30 \%$ grasses in maize silage also reduced the $\mathrm{N}-\mathrm{NH}_{3}$ content.

The exclusive Brachiaria species silages presented the lowest DM content, differing from the exclusive maize silage and maize with 30\% Xaraes and Paiaguas palisadegrass (Table 2). Maize silage presented a higher DM content compared with that of the other silages.

When the lactic acid concentration of the silages was determined (Table 3), higher values were observed for maize silage $(p<0.05)$. In contrast, the Brachiaria species silages showed lower lactic acid concentrations. The $30 \%$ grass addition had a positive effect since the lactic acid concentration increased compared with that in the exclusive grass silages. For the determination of the acetic and butyric acid concentrations (Table 3), the Brachiaria species silages exhibited higher contents compared with the exclusive maize silage $(p<0.05)$. The mixed silages presented mean values of 5.58 and $0.22 \mathrm{~g} \mathrm{~kg}^{-1} \mathrm{DM}$ for acetic and butyric acids, respectively. For the propionic acid concentration, only the maize silage was different $(p<0.05)$ from the other silages.

For the silage nutritive quality, the Paiaguas palisadegrass silage stood out, exhibiting a higher CP value, representing a $57.50 \%$ increase compared with that for maize silage (Table 4). Regarding the EE content, a higher value was observed in exclusive maize silage (Table 4), differing from the results for the grass and mixed silages. However, the inclusion of Brachiaria species at $30 \%$ resulted in an increase in the $\mathrm{EE}$ content compared with that of the exclusive grass silages.

For the determination of silage TDN contents (Table 4), a direct relationship with the EE was observed. As the silages presented higher EE values, they showed an increase in TDN contents. Therefore, it was verified that the highest EE and TDN contents were observed for exclusive maize silage.

The highest NDF contents (Table 5) were observed in Brachiaria species silages. The tropical grass inclusion in maize silage provided lower NDF contents compared with those of exclusive grass silages.
For ADF and lignin contents (Table 5), it was observed that Congo grass and Xaraes palisadegrass silages exhibited the highest ADF values. Moreover, Paiaguas palisadegrass silage presented average ADF and lignin contents similar to mixed silages. However, exclusive maize silage showed lower values compared with those of other silages.

The exclusive maize silage presented higher IVDMD values (Table 5), differing $(p<0.05)$ from the other silages. The inclusion of tropical grasses in the maize silage resulted in higher digestibility in the mixed silages, and the lowest IVDMD values were observed in exclusive grass silages.

\section{Discussion}

The relatively low $\mathrm{pH}$ value in the exclusive maize silage (Table 2) was due to the good silage fermentation, high soluble carbohydrate content (Brüning et al., 2017), and low content of buffering substances in the crop, resulting in a $\mathrm{pH}$ decrease. However, the exclusive Brachiaria species silages exhibited $\mathrm{pH}$ values above that recommended by McDonald et al. (1991), who indicated that the silage $\mathrm{pH}$ in a fermentation that was occurring properly must be between 3.8 and 4.2 , because within this range, there are restrictions on plant proteolytic enzymes as well as enterobacteria and clostridia (Zhang et al., 2016).

Tropical grass silages tend to stabilize at a higher $\mathrm{pH}$ due to their low DM content, high buffer capacity and low soluble carbohydrate content (Cezário et al., 2015). The exclusive Brachiaria species silages presented the above disadvantages, thus explaining their higher $\mathrm{pH}$ values.

Notably, that the mixed silages presented intermediate $\mathrm{pH}$ values. These results demonstrated the effectiveness of producing mixed maize silages with Brachiaria species. Maize contributed to decreasing $\mathrm{pH}$ values of the silages because it presents higher DM and soluble carbohydrate contents in relation to grasses; this resulted in adequate fermentation, promoting a faster decrease in silage $\mathrm{pH}$ and ensuring better silage quality (Tomich et al., 2004).

When evaluating the $\mathrm{pH}$ of maize silages intercropped with Xaraes palisadegrass in different planting systems, Leonel et al. (2009) did not find differences in the $\mathrm{pH}$ values between exclusive maize silage and intercropped silages, the values of which were between 3.51 and 3.55, respectively.

The higher buffer capacity (Table 2) obtained in the Brachiaria species silages is due to the presence of ions such as potassium $\left(\mathrm{K}^{+}\right)$, calcium $\left(\mathrm{Ca}^{2+}\right)$ and magnesium $\left(\mathrm{Mg}^{2+}\right)$, which are buffering substances that neutralize organic acids, thus inhibiting the $\mathrm{pH}$ reduction rate (Smith, 1962). Therefore, fermentation is impaired, which constitutes a barrier to rapid $\mathrm{pH}$ lowering, giving rise to poorly preserved forages.

The ensiled material should have a low buffer capacity to provide no resistance to $\mathrm{pH}$ reduction (McDonald et al., 1991). Considering the above, the maize silage showed the lowest buffer capacity, followed by the mixed silages. Thus, the mixed silages provide less resistance to $\mathrm{pH}$ reduction, ensuring better conservation of nutrients in the silage.

In general, the buffer capacity values found in all silages evaluated in the present study did not exceed the range recommended by Ferrari Júnior Lavezzo (2001), who indicated that values lower than 20 eq. $\mathrm{mg} \mathrm{HCl} 100 \mathrm{~g}^{-1} \mathrm{DM}$ are obtained for silages with adequate fermentation characteristics.

Similar to the $\mathrm{pH}$ and buffer capacity, the finding that the highest $\mathrm{N}-\mathrm{NH}_{3}$ content (Table 2) occurred in the exclusive Brachiaria species silages was probably due to their lower DM 
content (Table 1), higher buffer capacity and lower concentration of water-soluble carbohydrates that are readily available for lactic fermentation. These are characteristics that are usually found in tropical forages (Leonel et al., 2009), explaining the higher $\mathrm{N}-\mathrm{NH}_{3}$ of the exclusive Brachiaria species silages.

The maize silage presented the lowest protein deterioration, resulting in a lower $\mathrm{N}-\mathrm{NH}_{3}$ content compared with that of the other silages. The inclusion of Brachiaria species at $30 \%$ in maize silage resulted in a $\mathrm{N}^{-N_{3}}$ content that was intermediate to those in the exclusive silages, averaging $32.1 \mathrm{~g}$ $\mathrm{kg}^{-1}$. Therefore, mixed maize silages with tropical grasses contributed to a reduction in $\mathrm{N}-\mathrm{NH}_{3}$ values. This result was due to the high content of soluble sugars present in maize (approximately $160 \mathrm{~g} \mathrm{~kg}^{-1}$ (Brüning et al., 2017)), which are readily available for the fermentation of lactic acid-producing bacteria.

For exclusive Brachiaria species silages, the $\mathrm{N}-\mathrm{NH}_{3}$ values remained within the ideal range since according to Kung Jr. and Shaver (2001), to achieve adequate lactic fermentation, reduce proteolysis and inhibit the growth of undesirable microorganisms, silage should exhibit $\mathrm{N}-\mathrm{NH}_{3}$ contents below $100 \mathrm{~g} \mathrm{~kg}^{-1}$, indicating that even in exclusive tropical forage silages, there is little activity of members of the bacterial Clostridium genus. Consequently, there is no excessive protein deterioration without compromising the silage nutritive value. The lowest DM content in the Brachiaria species silages was due to the high water content of the plants. Even with cutting at 105 days of growth, the average DM value was $261.63 \mathrm{~g}$ $\mathrm{kg}^{-1}$, which was below the recommended value for plants cut for silage.

The DM content is one of the main factors to be considered in determining the ideal time for ensilage. According to Muck Shinners (2001), DM concentrations lower than $300 \mathrm{~g} \mathrm{~kg}^{-1}$ can increase effluent losses and result in a higher possibility of fermentation by Clostridium, leading to lower-quality silage and interfering with acceptability by animals. It was noted in the present study that exclusive maize silage presented 318.0 $\mathrm{g} \mathrm{kg}^{-1} \mathrm{DM}$, which was within the range established by the abovementioned authors.

According to Bergamaschine et al. (2006), tropical grasses present high moisture and low soluble carbohydrate contents, and these factors, when integrated, negatively affect the silage quality. However, the production of mixed silages contributed to an increase in DM, thus contributing to minimizing the undesirable effects on the fermentation process caused by the high water content present in tropical grasses at the cutting time.

The finding that the highest lactic acid concentration was obtained in the exclusive maize silage may have been due to the adequate soluble carbohydrate content (Filya \& Sucu, 2010), low pH and buffer capacity of maize. The high soluble carbohydrate content of maize $\left(160 \mathrm{~g} \mathrm{~kg}^{-1}\right)$ (Brüning et al., 2017) contributed to an increase in the lactic acid concentration in mixed silages. Thus, the mixed silages presented higher lactic acid concentrations compared with the exclusive grass silages, showing an advantage of this form of silage production because tropical grasses present low lactic acid concentrations.

Lactic acid plays a fundamental role in the fermentation process because it presents a higher dissociation constant than do other acids (Moisio \& Heikonem, 1994) and is responsible for the reduction in the $\mathrm{pH}$ below 4.20 . In this context, the inhibition of the bacterial Clostridium genus is responsible for undesirable fermentation products (Carvalho et al., 2016). This situation was verified in the present study because the exclusive maize silage and the mixed silages presented the highest lactic acid concentrations (Table 3); as a consequence, the $\mathrm{pH}$ reduction in these silages was greater.

When the classification criteria established by Roth Undersander (1995) was used, lactic acid concentrations in the range of 40 to $60 \mathrm{~g} \mathrm{~kg}^{-1}$ are considered to indicate good quality. Thus, it was observed that the lactic acid concentrations obtained in this study were below the range recommended by the authors mentioned above.

The finding that the highest acetic and butyric acid concentrations occurred in exclusive Brachiaria species silages may have been due to the lower DM content and higher $\mathrm{pH}$ value of these silages, which favours the development of the bacterial Clostridium genus (McDonald et al., 1991).

The competition for soluble sugars between lactic acid bacteria and enterobacteria in the early fermentation stages results in the high production of acetic acid, in addition to causing losses of DM and energy (McDonald et al., 1991). It also affects the animal's response since the fermentation pattern influences silage intake and digestibility.

Well-preserved silages must exhibit low concentrations of acetic and butyric acid, which can be used as a parameter for silage fermentation qualification. According to Roth Undersander (1995), the silage acetic acid concentrations determined in this study were within the range established as ideal, with acetic acid concentrations below the limit of $20.0 \mathrm{~g}$ $\mathrm{kg}^{-1}$ and butyric acid concentrations lower than $1.0 \mathrm{~g} \mathrm{~kg}^{-1} \mathrm{DM}$. Therefore, the growth of the bacterial Clostridium genus in ensiled mass may have been limited, contributing to the conservation of the nutritive value, mainly through proteolysis reduction (McDonald et al., 1991).

The finding that a lower propionic acid concentration occurred in the exclusive maize silage was due to its higher DM content and lower $\mathrm{pH}$, which prevents the development of the bacterial Clostridium genus (McDonald et al., 1991). According to Kung and Shaver (2001), a propionic acid concentration of $5.0 \mathrm{~g} \mathrm{~kg}^{-1}$ is ideal for good-quality silage. On the basis of this information, it could be verified that there was no deterioration of lactic acid caused by butyric acid-producing bacteria in this study since even the exclusive Brachiaria species silages were within the standard established in the literature.

The Paiaguas palisadegrass silage was characterized by the highest CP content. This result was due to the morphology of this species, which presents a higher leaf blade:stem ratio, thus producing forage with more nutritive value (Costa et al., 2016; Epifanio et al., 2019).

The exclusive maize silage presented the lowest CP content. However, there was an increase in the protein content of the mixed silages. That is, the inclusion of tropical forages at $30 \%$ in maize silage resulted in an improvement in the nutritive quality of the silages, which is considered the main advantage of mixed silage production.

According to Lazzarini et al. (2009), ruminants should receive a diet with at least $70 \mathrm{~g} \mathrm{~kg}^{-1} \mathrm{CP}$ to not compromise the efficiency of ruminal microorganisms in using the fibrous carbohydrates present in silages. Therefore, with the exception of the exclusive maize silage, the other silages presented CP contents that were higher than that recommended by the abovementioned authors.

The finding that the highest EE content occurred in the exclusive maize silage (Table 4) was due to the higher amount 
Table 1. Chemical-bromatological composition ( $\mathrm{g} \mathrm{kg}^{-1} \mathrm{DM}$ ) of maize and Brachiaria species before ensiling.

\begin{tabular}{|c|c|c|c|c|}
\hline Composition & Maize & $\begin{array}{l}\text { Congo } \\
\text { grass }\end{array}$ & Xaraes palisadegrass & Paiaguas palisadegrass \\
\hline DM & 338.6 & 277.9 & 263.1 & 286.4 \\
\hline $\mathrm{CP}$ & 75.5 & 85.1 & 92.3 & 109.5 \\
\hline $\mathrm{EE}$ & 45.4 & 18.1 & 19.1 & 18.8 \\
\hline TDN & 690.3 & 587.0 & 599.3 & 595.2 \\
\hline NDF & 532.0 & 709.6 & 712.2 & 697.1 \\
\hline ADF & 412.3 & 479.3 & 445.1 & 431.4 \\
\hline Lignin & 18.2 & 38.7 & 38.4 & 36.4 \\
\hline IVDMD & 668.8 & 522.2 & 524.2 & 556.1 \\
\hline
\end{tabular}

DM: dry matter; CP: crude protein; EE: ethereal extract; TDN: total digestible nutrients; NDF: neutral detergent fibre; ADF: acid detergent fibre; IVDMD: in vitro dry matter digestibility.

Table 2. Fermentative characteristics of silages from of exclusive maize and with Brachiaria species.

\begin{tabular}{|lcccc|}
\hline Silages & $\begin{array}{l}\mathrm{pH} \\
\text { Maize }\end{array}$ & $\begin{array}{l}\mathrm{BT} \\
\text { (eq. } \mathrm{mg} \mathrm{HCl} \mathrm{g} \mathrm{kg}^{-1} \\
\mathrm{DM})\end{array}$ & $\begin{array}{c}\mathrm{N}-\mathrm{NH}_{3} \\
\left(\mathrm{~g} \mathrm{~kg}^{-1} \mathrm{DM}\right)\end{array}$ & $\begin{array}{l}\mathrm{DM} \\
\left(\mathrm{g} \mathrm{kg}^{-1} \mathrm{DM}\right)\end{array}$ \\
\hline Ruziziensis grass & $3.70 \mathrm{c}$ & $8.25 \mathrm{c}$ & $20.60 \mathrm{c}$ & $318.0 \mathrm{a}$ \\
\hline Xaraes palisadegrass & $4.69 \mathrm{a}$ & $13.97 \mathrm{a}$ & $46.55 \mathrm{a}$ & $250.17 \mathrm{c}$ \\
\hline Paiaguas palisadegrass & $4.76 \mathrm{a}$ & $14.87 \mathrm{a}$ & $47.70 \mathrm{a}$ & $263.37 \mathrm{c}$ \\
\hline Maize + 30\% Ruziziensis grass & $4.80 \mathrm{a}$ & $14.37 \mathrm{a}$ & $49.77 \mathrm{a}$ & $271.57 \mathrm{c}$ \\
\hline Maize + 30\% Xaraes palisadegrass & $4.19 \mathrm{~b}$ & $12.07 \mathrm{~b}$ & $32.22 \mathrm{~b}$ & $280.70 \mathrm{bc}$ \\
\hline Maize + 30\% Paiaguas palisadegrass & $4.17 \mathrm{~b}$ & $11.72 \mathrm{~b}$ & $33.92 \mathrm{~b}$ & $296.75 \mathrm{~b}$ \\
\hline CV (\%) & $4.24 \mathrm{~b}$ & $12.17 \mathrm{~b}$ & $30.27 \mathrm{~b}$ & $292.32 \mathrm{~b}$ \\
\hline Means followed by different letters differ according to Tukey's test at 5\% probability. BT: buffer capacity; N-NH3: ammoniacal nitrogen; DM: dry matter.
\end{tabular}

Table 3. Organic acids ( $\mathrm{g} \mathrm{kg}^{-1} \mathrm{DM}$ ) of silages from of exclusive maize and with Brachiaria species.

\begin{tabular}{|c|c|c|c|c|}
\hline Silages & Lactic acid & Acetic acid & Propionic acid & Butyric acid \\
\hline Maize & $35.72 \mathrm{a}$ & $3.63 \mathrm{c}$ & $1.83 \mathrm{~b}$ & $0.15 c$ \\
\hline Congo grass & $14.30 \mathrm{c}$ & $7.85 \mathrm{a}$ & $4.59 \mathrm{a}$ & $0.33 \mathrm{a}$ \\
\hline Xaraes palisadegrass & $15.32 \mathrm{c}$ & $7.81 \mathrm{a}$ & $4.50 \mathrm{a}$ & $0.34 \mathrm{a}$ \\
\hline Paiaguas palisadegrass & $15.27 \mathrm{c}$ & $7.83 \mathrm{a}$ & $4.29 \mathrm{a}$ & $0.30 \mathrm{a}$ \\
\hline Maize $+30 \%$ Congo grass & $24.89 b$ & $5.62 \mathrm{~b}$ & $4.35 \mathrm{a}$ & $0.22 \mathrm{~b}$ \\
\hline Maize $+30 \%$ Xaraes palisadegrass & $25.44 \mathrm{~b}$ & $5.51 \mathrm{~b}$ & $4.22 \mathrm{a}$ & $0.21 \mathrm{~b}$ \\
\hline Maize $+30 \%$ Paiaguas palisadegrass & $25.26 \mathrm{~b}$ & $5.62 \mathrm{~b}$ & $4.33 \mathrm{a}$ & $0.23 \mathrm{~b}$ \\
\hline CV (\%) & 15.32 & 12.91 & 20.34 & 13.81 \\
\hline
\end{tabular}

Means followed by different letters differ according to Tukey's test at $5 \%$ probability.

Table 4. $\mathrm{CP}, \mathrm{EE}$ and TDN contents ( $\mathrm{g} \mathrm{kg}^{-1} \mathrm{DM}$ ) of silages from of exclusive maize and with Brachiaria species.

\begin{tabular}{|lccc|}
\hline Silages & \multicolumn{1}{c}{ CP } & EE & TDN \\
\hline Maize & $64.60 \mathrm{~d}$ & $43.7 \mathrm{a}$ & $649.07 \mathrm{a}$ \\
\hline Congo grass & $82.55 \mathrm{~b}$ & $18.12 \mathrm{c}$ & $590.92 \mathrm{c}$ \\
\hline Xaraes palisadegrass & $92.22 \mathrm{~b}$ & $19.15 \mathrm{c}$ & $586.95 \mathrm{c}$ \\
\hline Paiaguas palisadegrass & $101.75 \mathrm{a}$ & $18.57 \mathrm{c}$ & $578.50 \mathrm{c}$ \\
\hline Maize + 30\% Congo grass & $72.50 \mathrm{c}$ & $24.15 \mathrm{~b}$ & $610.90 \mathrm{~b}$ \\
\hline Maize + 30\% Xaraes palisadegrass & $85.10 \mathrm{bc}$ & $27.32 \mathrm{~b}$ & $614.35 \mathrm{~b}$ \\
\hline Maize + 30\% Paiaguas palisadegrass & $85.07 \mathrm{bc}$ & $26.15 \mathrm{~b}$ & $612.75 \mathrm{~b}$ \\
\hline CV (\%) & 6.51 & 14.62 & 2.28 \\
\hline
\end{tabular}

Means followed by different letters differ according to Tukey's test at 5\% probability. CP: crude protein; EE: ethereal extract; TDN: total digestible nutrient 
Table 5. NDF, ADF, lignin and DIVMS contents ( $\left.\mathrm{g} \mathrm{kg}^{-1} \mathrm{DM}\right)$ of silages from of exclusive maize and with Brachiaria species.

\begin{tabular}{|lcccc|}
\hline Silages & NDF & ADF & Lignin & IVDMD \\
\hline Maize & $549.12 \mathrm{c}$ & $329.17 \mathrm{~d}$ & $23.45 \mathrm{~d}$ & $640.50 \mathrm{a}$ \\
\hline Congo grass & $693.65 \mathrm{a}$ & $434.67 \mathrm{a}$ & $43.47 \mathrm{a}$ & $500.77 \mathrm{c}$ \\
\hline Xaraes palisadegrass & $700.67 \mathrm{a}$ & $422.55 \mathrm{a}$ & $39.67 \mathrm{a}$ & $520.12 \mathrm{c}$ \\
\hline Paiaguas palisadegrass & $700.42 \mathrm{a}$ & $409.50 \mathrm{bc}$ & $36.45 \mathrm{bc}$ & $554.12 \mathrm{c}$ \\
\hline Maize $+30 \%$ Congo grass & $654.17 \mathrm{~b}$ & $400.55 \mathrm{c}$ & $30.87 \mathrm{c}$ & $567.35 \mathrm{~b}$ \\
\hline Maize $+30 \%$ Xaraes palisadegrass & $648.17 \mathrm{~b}$ & $386.67 \mathrm{c}$ & $29.17 \mathrm{c}$ & $585.52 \mathrm{~b}$ \\
\hline Maize $+30 \%$ Paiaguas palisadegrass & $642.00 \mathrm{~b}$ & $377.72 \mathrm{c}$ & $27.50 \mathrm{c}$ & $593.80 \mathrm{~b}$ \\
\hline CV (\%) & 2.22 & 3.17 & 9.57 & 5.33 \\
\hline
\end{tabular}

Media followed by different letters differs according to Tukey's test at 5\% probability. NDF: neutral detergent fibre; ADF: acid detergent fibre; IVDMD: in vitro dry matter digestibility.

of fats contained in the maize grain (Perim et al., 2014). Thus, mixed silages presented higher levels than the exclusive Brachiaria species silages, where maize contributed to improving the energy quality of the food since tropical forages are low in fat.

For the TDN contents (Table 4), similar behaviour to the EE contents was observed. The highest TDN content in the exclusive maize silage was due to the higher EE content. However, the exclusive Brachiaria species silages presented lower TDN contents, and the mixed silages showed intermediate TDN contents compared with those of the exclusive maize and grass silages.

Therefore, a relevant factor in the decision to produce mixed silages is related to the energy and protein balance resulting from this association, which becomes significant, as observed in the present study.

By evaluating the silage quality of maize and Brachiaria brizantha cv. Xaraes in different planting systems, Leonel et al. (2009) reported TDN contents of 598.1, 503.1, 592.2 and 612.3 $\mathrm{g} \mathrm{kg}^{-1}$ for maize only, Brachiaria only, maize and Brachiaria in a row and between rows of maize and Brachiaria, respectively. Their results were similar to those found in this study.

The exclusive Brachiaria species silages exhibited higher NDF, ADF and lignin contents (Table 5) because tropical grasses present higher fibrous fractions. However, when mixed maize and tropical forage silages were produced, there was a fibre dilution effect due to the lower NDF, ADF and lignin contents of maize (Table 1), possibly favouring the intake and digestibility of these silages.

Higher ADF values result in the unavailability of degradable structural carbohydrates since the lignin present in the cell wall prevents microbial adhesion and the enzymatic hydrolysis of cellulose and hemicellulose, reducing fibre digestibility (Epifanio et al., 2016). In addition, the ADF content recommended in the literature is close to $400 \mathrm{~g} \mathrm{~kg}^{-1}$ (Van Soest, 1994). Therefore, the results obtained for exclusive maize silage and maize $+30 \%$ Brachiaria species were within the range recommended in the literature, again demonstrating the advantage of producing mixed silage.

The higher non-structural carbohydrate contents of maize, such as the starch content, are related to the higher IVDMD of exclusive maize silage (Table 4). Therefore, silage production involving maize mixed with Brachiaria species can be an effective alternative to increase the silage IVDMD compared with that of exclusive grass silages, in addition to providing better silage fermentation conditions.

According to Van Soest (1994), an increase in IVDMD occurs with the addition of material that has a higher content of non-fibrous carbohydrates, such as starch, pectin and sugars, which are more digestible than structural carbohydrates, such as cellulose and hemicellulose. Justifying the results of this study, the exclusive tropical forage silages presented higher NDF, ADF and lignin contents, leading to the lowest IVDMD values (Jayme et al., 2007).

\section{Materials and methods}

\section{Experimental site description}

The experiment was carried out in the field $\left(17^{\circ} 48^{\prime} \mathrm{S}, 50^{\circ} 55^{\prime}\right.$ $\mathrm{W}$ and $748 \mathrm{~m}$ altitude) in Rio Verde, Goias. Before the beginning of the experiment, deformed soil samples were collected from the area with the aid of a Dutch soil auger at a $0-20 \mathrm{~cm}$ depth for soil chemical analysis. The soil of the experimental area was characterized as a Dystroferric Red Latosol (Santos et al., 2018). The characteristics of the soil were as follows: 450,200 , and $350 \mathrm{~g} \mathrm{~kg}^{-1}$ clay, silt and sand, respectively; $\mathrm{pH}$ in $\mathrm{CaCl}_{2}, 5.4 ; \mathrm{Ca}, 2.1 \mathrm{cmol}_{\mathrm{c}} \mathrm{dm}^{-3} ; \mathrm{Mg}, 1.3 \mathrm{cmol}_{\mathrm{c}}$ $\mathrm{dm}^{-3} ; \mathrm{Al}, 0.05 \mathrm{cmol}_{\mathrm{c}} \mathrm{dm}^{-3} ; \mathrm{Al}+\mathrm{H}, 2.3 \mathrm{cmol}_{\mathrm{c}} \mathrm{dm}^{-3} ; \mathrm{K}, 0.24 \mathrm{cmol}_{\mathrm{c}}$ $\mathrm{dm}^{-3}$; cation exchange capacity (CEC), $5.94 \mathrm{cmol}_{\mathrm{c}} \mathrm{dm}^{-3} ; \mathrm{V} 1$, 61.34\%; P (Mehlich), $1.2 \mathrm{mg} \mathrm{dm}^{-3}$; and MO, $27.5 \mathrm{~g} \mathrm{~kg}^{-1}$.

\section{Statistical design, treatments, and crop planting}

The experimental design was completely randomized with four replications. The treatments consisted of the following silages: maize (Zea mays); Congo grass (Brachiaria ruziziensis); Xaraes palisadegrass (Brachiaria brizantha cv. Xaraes); Paiaguas palisadegrass (Brachiaria brizantha cv. BRS Paiaguas); maize $+30 \%$ Congo grass; maize $+30 \%$ Xaraes palisadegrass, and maize $+30 \%$ Paiaguas palisadegrass. The mechanical sowing of maize and forage was performed with MF 510 double disc seeders, and the maize hybrid used was $\mathrm{P} 3779 \mathrm{H}$. With respect to fertilization, $200 \mathrm{~kg} \mathrm{ha}^{-1}$ of $\mathrm{P}_{2} \mathrm{O}_{5}$ and $40 \mathrm{~kg} \mathrm{ha}^{-1}$ of $\mathrm{K}_{2} \mathrm{O}$ were applied as simple superphosphate and potassium chloride, respectively, and for cover fertilization, $100 \mathrm{~kg} \mathrm{ha}^{-1}$ of nitrogen was applied, divided into two applications - at the V4 and V6 stages of the maize. For culture implementation, a spacing of $50 \mathrm{~cm}$ was used for maize, and the forage was sown in the inter-rows with a spacing of $25 \mathrm{~cm}$. Both species were sown at a $2 \mathrm{~cm}$ depth. Each plot was $14 \mathrm{~m}$ long and $6.5 \mathrm{~m}$ wide. The useful areas to be used for silage production were the four central lines, with $0.5 \mathrm{~m}$ removed from each end.During the experiment, a phytosanitary control was performed with two applications of the chlorfenapyr insecticide at a rate of $0.5 \mathrm{~L} \mathrm{ha}^{-1}$ of the commercial product in a costal sprayer. Weed control was performed through manual weeding.

\section{Ensilage}

For the ensilage process, maize and grasses were harvested in a 105-day cycle, and the maize DM content was $338 \mathrm{~g} \mathrm{~kg}^{-1}$. The forages were cut separately at a height of $20 \mathrm{~cm}$ from the soil using a costal harvester. Subsequently, the forages were 
chopped separately into particles of approximately $10 \mathrm{~mm}$ via a stationary chopper. Then, the material was homogenized by fixing the inclusion of $30 \%$ of each grass based on natural matter.

The material was stored in experimental PVC silos, measuring $10 \mathrm{~cm}$ in diameter and $40 \mathrm{~cm}$ in length. Subsequently, it was compacted with an iron pendulum, and the silos were closed with PVC caps and sealed with adhesive tape to prevent the entry of air. The average density in the silos was $1.12 \mathrm{~kg} \mathrm{dm}^{3}$. Thereafter, the experimental silos were kept in a covered area at room temperature.

\section{Chemical-bromatological analyses}

Chemical-bromatological analyses of the in natura material (before ensiling) (Table 1) were carried out according to the methods described by the AOAC (1990) to determine the DM; $\mathrm{CP}$, obtained via the determination of the total $\mathrm{N}$ with a correction factor of 6.25; EE; and ADF. The NDF content was determined according to the methods of Mertens (2002), and the lignin was determined according to the methods of Van Soest \& Robertson (1985). The TDN were obtained with the equation proposed by Chandler (1990). The technique described by Tilley and Terry (1963) adapted to the artificial rumen and developed by ANKON $^{\circledR}$ was used to determine the IVDMD.

\section{Opening of silos, analysis of fermentative and chemical-bromatological characteristics}

After 50 days of ensilage, the silos were opened, and the upper and lower portions of the contents of each silo were discarded. The central portion of the silo contents was homogenized and placed in plastic trays. A portion of the in natura silage was separated for the analysis of fermentative parameters such as the buffer capacity, $\mathrm{pH}$ and ammoniacal nitrogen in relation to the total nitrogen $\left(\mathrm{N}-\mathrm{NH}_{3} \mathrm{NT}^{-1}\right)$.

The $\mathrm{pH}$ and the $\mathrm{N}-\mathrm{NH}_{3}$ content were determined by the methods described by Bolsen et al. (1992) [24], and the buffer capacity (eq. $\mathrm{mg} \mathrm{HCl} 100 \mathrm{~g}^{-1} \mathrm{DM}$ ) was determined according to Silva \& Queiroz (2002). The contents of organic acids (lactic, acetic, propionic and butyric acids) were determined via a high-performance liquid chromatograph (HPLC) according to the method described by Kung Jr (1996).

The other portion of the samples of approximately $0.5 \mathrm{~kg}$ was weighed, placed in a forced ventilation oven at $55^{\circ} \mathrm{C}$ for 72 hours and then milled in knife mill with a $1 \mathrm{~mm}$ sieve and stored in plastic containers to analyse the same chemical-bromatological characteristics described for the in natura material.

\section{Statistical analysis}

The variables were subjected to variance analysis with the $R$ program, version R-3.1.1., with the ExpDes package (Ferreira et al., 2014). The averages were compared with Tukey's test, with a significance level of $5 \%$.

\section{Conclusions}

The inclusion of Brachiaria species at $30 \%$ in maize silage produced results that supported their inclusion based on fermentation parameters, since adequate $\mathrm{pH}$, buffer capacity, $\mathrm{N}-\mathrm{NH}_{3}$ and organic acid values were demonstrated, in addition to providing silage with better nutritive value. Thus, this approach may represent another alternative for supplying the bulk deficit in the dry season.
Among the Brachiaria species used, the Paiaguas palisadegrass was distinguished by a higher protein content and low ADF content, leading to its recommendation for use in mixed silage production.

The exclusive Brachiaria species silages showed lower nutritive values because they presented a higher proportion of unavailable fractions or slow degradation of protein and carbohydrate fractions, which may compromise animal performance.

\section{Acknowledgements}

The authors would like to thank the Instituto Federal Goiano for financially supporting this study.

\section{References}

Anésio AHC, Santos MV, Da Silva LD, Silveira RR, Braz TGS, Pereira, R.C (2017) Effects of ensiling density on chemical and microbiological characteristics of sorghum silage. J Anim Feed Sci. 26: 65-69.

Association of Official Analytical Chemists - AOAC (1990) Official methods of analysis (15 ed), Washington DC: 1298.

Bergamaschine AF, Passipiéri $\mathrm{M}$, Veriano Filho WV, Isepon OJ, Correa LDA (2006) Qualidade e valor nutritivo de silagens de capim-marandu (B. brizantha $\mathrm{cv}$. Marandu) produzidas com aditivos ou forragem emurchecida. $R$ Bras Zootec. 35: 1454-1462.

Bolsen KK, Lin C, Brent BE, Feyerherm AM, Urban JE, Aimutis WR (1992) Effect of silage additives on the microbial succession and fermentation process of alfalfa and corn silages. J Dairy Sci. 75, 3066-3083.

Borges BRS, Negrão FM, Zanine AM, Machado A, Caldeira FHB, Lins TOJD (2018) Potencial da ensilagem de capim-braquiária com inclusão de farelo de arroz. Pubvet. 12: 1-9.

Brüning D, Gerlach K, Weiß K, Südekum K (2017) Effect of compaction, delayed sealing and aerobic exposure on forage choice and short-term intake of maize silage by goats. Grass Forage Sci. 73: 53-66.

Carvalho AFG, Martin, TN, Santos S, Müller TM, Piran Filho FA (2016) Perfil agronômico e bromatológico de silagem de milho no sudoeste do Paraná. Ver. Fac. Agron. 114: 149-159.

Cezário AS, Ribeiro KG, Santos S, Valadares Filho SC, Pereira OG (2015) Marandu harvested at two regrowth ages: microbial inoculant responses in silage fermentation, ruminant digestion and beef cattle performance. J Anim Feed Sci. 208: 33-43.

Chandler P (1990) Energy predictionoffeedsby forage testingexplorer. Feedstuffs, 62-12.

Costa KAP, Assis RL, Guimarães KC, Severiano EC, Assis Neto JM, Crunivel WS, Garcia JF, Santos NF (2011) Silage quality of Brachiaria brizantha cultivars ensiled with different levels of millet meal. Arq Bras Med Vet Zootec. 63: 188-195.

Costa RRGF, Costa KAP, Santos CB, Severiano EC, Epifânio PS, Silva JT, Teixeira DAA, Silva VR (2016) Production and nutritional characteristics of pearl millet and Paiaguas palisadegrass under different forage systems and sowing periods in the offseason. Afr J Agric Res. 11: 1712-1723.

Costa RRGF, Costa KAP, Souza WF, Epifanio PS, Santos CB, Silva JT, Oliveira SS (2018) Production and quality of silages pearl millet and Paiaguas palisadegrass in monocropping and intercropping in different forage systems. Bioscience. 34: 957-967. 
Cozzi G, Mazzenga A, Contiero B, Burato G (2008) Use of maize silage in beef cattle feeding during the finishing period. J Anim Sci. 7: 39-52.

Cruvinel, WS, Costa, KAP, Teixeira, DAA, Da Silva, JT, Epifanio, PS, Costa, PHCP \& Fernandes, PB. 2017. Fermentation profile and nutritive value of sunflower silage with Urochloa brizantha cultivars in the off-season. Rev Bras Saúde Prod Anim. 18: 249-259.

Epifanio PS, Costa KAP, Severiano EC, Cruvinel WS, Bento JC, Perim RC (2014) Fermentative and bromatological characteristics of Piata palisadegrass ensiled with levels of meals from biodiesel industry. Semina Ciênc Agrár. 35: 491-504.

Epifanio PS, Costa KAP, Severiano EC, Souza WF, Teixeira DAA, Silva JT, Aquino MM (2019) Productive and nutritional characteristics of Brachiaria brizantha cultivars intercropped with Stylosanthes cv. Campo Grande in different forage systems. Crop Pasture Sci. 70: 718-729.

Epifanio PS, Costa KAP, Guarnieri A, Teixeira DAA, Oliveira SS, Silva VR (2016) Silage quality of Urochloa brizantha cultivars with levels of campo grande Stylosanthes. Acta Sci Anim Sci. 38: 135-142.

Ferrari Júnior E, Lavezzo W (2001) Qualidade da silagem de capim-elefante (Pennisetum purpureum Schum.) Emurchecido ou acrescido de farelo de mandioca. R Bras Zootec. 30: 1424-1431.

Ferreira EB, Cavalcanti PP, Nogueira DA (2014) ExpDes: An R Package for ANOVA and Experimental Designs. J Appl Math. 5: 2952-2958.

Filya I, Sucu E (2010) The effects of lactic acid bacteria on the fermentation, aerobic stability and nutritive value of maize silage. Grass Forage Sci. 65: 446-455.

Garcia CMDP, Andreotti M, Teixeira Filho MCM, Buzetti S, Celestrino TDS, Lopes KSM (2013) Agronomic performance of corn and forages species in Crop-Livestock Integration system in the Cerrado. Cienc Rural. 43: 589-595.

Jayme DG, Gonçalves LC, Rodrigues JAS, Pires DAA, Guimarães Júnior RNM, Borges I, Borges ALCC, Saliba EOS, Jayme CG (2007) Qualidade das silagens de genótipos de girassol (Helianthus annuus) confeiteiros e produtores de óleo. Arq Bras Med Vet Zootec. 59: 1287-1293.

Kung Júnior L, (1996) Use of additives in silage fermentation. In: Direct-fed Microbial, Enzyme and Forage Additive Compendium. 37-42.

Kung Júnior L, Shaver R (2001) Interpretation and use of silage fermentation analysis reports. University of Wisconsin Board of Regents. Focus on Forage. 3: 1-5.

Lazzarini I, Detmann E, Sampaio CB, Paulino MF, Valadares Filho SC, Souza MA, Oliveira FA (2009) Intake and digestibility in cattle fed low-quality tropical forage and supplemented with nitrogenous compounds. R Bras Zootec. 38: 2021- 2030

Leonel FPL, Pereira JC, Costa MG, Marco Júnior P, Da Silva CJ, Lara LA (2009) Consórcio capim-braquiária e milho: comportamento produtivo das culturas e características nutricionais e qualitativas das silagens. $\mathrm{R}$ Bras Zootec. 38: 166-176.

Machado FS, Rodríguez NM, Gonçalves LC, Rodrigues JAS, Ribas, MN, Pôssas FP, Guimarães Júnior R, Jayme DG, Pereira LGR (2011) Consumo e digestibilidade aparente de silagens de sorgo em diferentes estádios de maturação. Arq Bras Med Vet Zootec. 63: 1470-1478.

McDonald P, Henderson AR, Heron SJE (1991). The biochemistry of silage. 2ed. Marlow: Chalcombe Pub. 340.
Mendes, GA, Rocha Júnior VR, Ruas JRM, Pereira MEG, Silva FV, Caldeira LA, Costa MD, Alves DD, Aguiar ACR (2014) Substituição da silagem de sorgo por silagem de capim-marandu: consumo, digestibilidade e ganho de peso. Rev Bras Ciênc Vet. 21: 44-52.

Mertens DR (1987) Predicting intake and digestibility using mathematical models of ruminal function. J Animal Sci. 64: 1548-1558.

Mertens DR (2002) Gravimetric determination of amylase-treated neutral detergent fiber in feeds with refluxing in beaker or crucibles: collaborative study. J AOAC Int. 85: 1217-1240.

Moisio T, Heikonem M (1994) Latic acid fermentation on silage preserved with formic acid. Anim Feed Sci. 47 107-124.

Muck RE, Shinners KJ (2001) Conserved forage (silage an hay): progress an priorities. International Grassland Congress. São Pedro. Piracicaba, Brasil, FEALQ, 753.

Oliveira SS, Costa KAP, Souza WF, Santos CB, Teixeira DAA, Silva VC (2020) Production and quality of the silage of sorghum intercropped with Paiaguas palisadegrass in different forage systems and at different maturity stages. Anim Prod Sci. 60: 1-11.

Paludo F, Costa, KAP, Dias MBC, Santos FA, Silva ACG, Rodrigues LG, Silva SAA, Souza WF, Bilego UO, Muniz MP (2020). Fermentative profile and nutritive value of corn silage with Tamani guinea grass. Semina Ciênc Agrár. 41: 2733-2746.

Paziani SF, Duarte AP, Nussio LG, Gallo PB, Bittar CMM, Zopollatto M, Reco PC (2009) Características agronômicas e bromatológicas de híbridos de milho para produção de silagem. R Bras Zootec. 38: 411-417.

Perim RC, Costa KAP, Epifanio OS, Souza WF, Francischini R, Teixeira DAA, Carvalho WG, Santos Júnior DR (2014). Fermentative and bromatological characteristics of Piata Palisadegrass ensiled with energetic brans. Am J Plant Sci. 5: 942-954.

Roth G, Undersander D (1995) Silage additives. Corn Silage Production Management and Feeding. MADISON: Madison American Society of Agronomy. 27-29.

Santos CB, Costa KAP, Souza WF, Oliveira IP, Teixeira DAA, Costa JVCP (2020) Production and quality of sunflower and Paiaguas palisadegrass silage in monocropped and intercropping in different forage systems. Acta Sci Anim Sci. 42: 48304

Santos HG, Jacomine PKT, Anjos LHC, Oliveira VA, Lumbreras, JF, Coelho MR, Almeida JA, Araujo Filho KC, Oliveira JB, Cunha TJF (2018) Sistema Brasileiro de Classificação de Solos, 5ed., Embrapa Solos: Brasília, Brasil.

Silva DJ, Queiroz AC (2002) Análise de alimentos: métodos químicos e biológicos. UFV:Viçosa- MG, Brasil.

Smith, L.H. (1962). Theoretical carbohydrate requirement for alfalfa silage production. J Agron. 54: 291-303.

Souza WF, Costa KAP, Guarnieri A, Severiano EC, Silva JT, Teixeira DAA, Oliveira SS, Dias MBC (2019) Production and quality of the silage of corn intercropped with Paiaguas palisadegrass in different forage systems and maturity stages. R Bras Zootec. 48: 1-16.

Tilley JMA, Terry RA (1963) A two-stage technique of the "in vitro" digestion of forage crop. J Br Grassl Soc. 18: 104-111.

Tomich TR, Gonçalves LC, Tomich RGP, Rodrigues JAS, Borges I, Rodriguez NM (2004). Características químicas e digestibilidade in vitro de silagens de girassol. $\mathrm{R}$ Bras Zootec. 33: 1672-1682. 
Van Soest PJ, Robertson JB (1985) Analysis of Forages and Fibrous Foods. Cornell University, Ithaca.

Van Soest PJ (1994) Nutritional ecology of the ruminant. 2ed. Ithaca: Cornell University Press.
Zhang, S, Abdul, SC, Diky R, Amerjan O, Guo X, Grant RE, Long $C$ (2016) Chemical composition and in vitro fermentation characteristics of high sugar forage sorghum as an alternative to forage maize for silage making in Tarim Basin, China. J Integr Agric. 15, 175-182. 